\title{
Water Treatment Emergency: Cost Evaluation Tools
}

\author{
Giovanna Acampa *(D), Maria Gabriella Giustra and Claudia Mariaserena Parisi \\ Faculty of Engineering and Architecture, University "Kore" of Enna, 94100 Enna, Italy; \\ mariagabriella.giustra@unikore.it (M.G.G.); claudia.parisi@unikore.it (C.M.P.) \\ * Correspondence: giovanna.acampa@unikore.it; Tel.: +39-0935-536-439
}

Received: 21 March 2019; Accepted: 30 April 2019; Published: 7 May 2019

\begin{abstract}
The European Union is committed to enforce limitations to water pollution through specific directives (UWWTD 91/271/EEC). The delay of some EU member states in transposing these directives has had an impact on the quality of the wastewater treatment system. Therefore, it is necessary to intervene with adjustment procedures and construction of new plants. The aim of the study is to carry out an economic feasibility assessment for the construction costs of an urban wastewater treatment plant of medium-low capacity ( $<50,000$ Population Equivalent or pe) according to a simplified process diagram, and help in the planning of new investments. We propose a methodology based on cost functions according to two different procedures: synthetic estimate of the costs for civil works and a multiple linear regression for the cost of the electromechanical equipment. These functions show a correlation between the construction costs and the population equivalent and enable us to understand it. The results show greater economic benefit in increasing wastewater treatment plants sizes serving a population equivalent of 5000 pe to 10,000 pe, while further increases are less beneficial.
\end{abstract}

Keywords: cost evaluation; parametric cost; multiple linear regression; wastewater management

\section{Introduction}

Wastewater is defined as any water whose quality has been adversely affected by anthropogenic influence after being used in domestic, industrial or agricultural activities. It is not suitable to be released in the environment (land, sea, rivers and lakes) without causing imbalances in the ecosystem.

The Council Directive concerning urban wastewater treatment, 91/271/EEC [1], requires that urban wastewater discharges should be regulated according to the quality objectives of the receiving water bodies. Therefore, wastewater from urban sewage systems must be treated appropriately (chemically, physically and biologically), depending on the type of wastewater and of the receiving water body. Wastewater treatment plants are the key infrastructure to reduce pollution of surface and groundwater bodies and to safeguard the health of the population [2].

As part of an integrated approach to water management, in addition to water-saving measures, the treatment and reuse of wastewater offers a reliable water supply alternative.

In this context, the new rules include the concept of an 'action plan on the circular economy', with the dual aim to ensure the protection of European water resources and reduce the waste that is currently produced [3].

The European Union is committed to regulate the sector in terms of exploitation, protection and safeguarding of the water through directives that impose on member states limits to pollution.

The Urban Waste Water Treatment Directive (UWWTD 91/271/EEC) is one of the main tools of the European water policy. The European Commission requests the "Office International de $l^{\prime} E a u^{\prime \prime}$ to prepare every two years a report providing data on the degree of implementation of the directive's provisions. 
The last report (2017) [4] summarizes the compliance status of the 28 member states with regard to the sewage system (article three), secondary treatment (article four) and tertiary treatment (article five).

Compliance is assessed by comparing the amount of wastewater load that is treated according to the UWWTD (i.e., water which is collected, gets secondary treatment and tertiary treatment) with the amount that theoretically should receive such treatment (the so called "subjected load").

Despite EU requirements, the report shows that some member states, such as Italy and especially the Sicily region, are still far from complying with the directives.

The delay of some EU member states in transposing these directives has had an impact on the quality of the wastewater treatment system. Therefore, it has been necessary to intervene with adjustment procedures and construction of new plants.

Assessing the costs of wastewater treatment is one of the most important and crucial aspects in the feasibility and sustainability assessment of a wastewater recovery and reuse project [5]. Certainly, it is not always easy to achieve comprehensive knowledge of the costs associated with each treatment process nor obtain comparable figures for various technologies. A detailed cost analysis by process is therefore required to make useful cost predictions for operating plants, and for simulating new facilities [6].

The existing literature on the technical and economic evaluation of wastewater treatment is quite extensive.

The cost-benefit analysis (CBA) and, more recently, the life-cycle assessment (LCA) [7] are the most widely applied tools to evaluate the feasibility of water and wastewater management programs [8].

Molinos-Senante et al. (2010) carried out a cost-benefit analysis of wastewater treatment taking into account only operational costs (energy, staff, reagents, water management and maintenance) to be compared to the benefits obtained by the removal of undesirable pollutants (TSS, N, P, etc.) [9]. Godfrey et al. (2009) carried out a cost-benefit analysis applied to a greywater reuse system using conventional economic methods for valuation like hedonic prices and contingent valuation [10]. Likewise, Seguí et al. (2009) used travel cost method to determine the environmental benefits arising from wastewater reuse in the context of a wetland restoration project [11]. Chen and Wang (2009) propose a net benefit value model for the cost-benefit evaluation of reuse projects which is applied in a residential area of China [12]. The literature shows that in most applications related to water resources the quantification of these externalities has been made using the contingent valuation method (CVM) [13-15].

The methodological approaches concerning the evaluation of the technical construction cost of wastewater treatment plants have been discussed widely in the literature since the late 1960s.

If the plants are divided by size, population served, type of wastewater and treatment, the unit costs decrease as the size of the plant increases [16]. On the other hand, if plants are divided as above and thus the sample considered becomes quite homogenous, inevitably the analysis is carried out on a smaller number of plants which inevitably causes difficulties in the statistical analysis of the data. This is a limit if historical prices are parameterized to a single synthetic indicator such as water supply, size of population served, removal efficiency referring to the main pollutants [17].

If the system is divided into "operating units" or treatment units and each of these into civil works and electromechanical equipment, it is possible to develop cost functions in relation to the specific characteristics of each unit $[18,19]$. For example, D'Antonio et al. have tried to relate the costs to the physical parameters (tank volume, transverse area, installed electrical power, etc.) of the primary and secondary sedimentation and oxidation units [20].

Irolli (2003) carried out a study on standard costs related to the population equivalent and the size of the tanks regardless of the treatment technology [21].

Parametric cost data for small plants (up to 10,000 habitants) were analyzed by different research teams, based on the size of the population served or on the square meters of required area. The EPA (2002) [22] and CIRIA [23] provided data on the construction costs of compact prefabricated plants. Upton et al. (1995) [24], Greenens and Thoeye (2000) [25] and Pergetti and Salsi (2002) [26] analyzed the costs of natural systems such as phytodepuration, sand filtration, biodiscs, etc., in order to determine the most suitable solution. 
Fortune and Lees (1996) [27] and Fortune and Hinks (1998) [28] identified multiple linear regression as one of the sixteen most widely used "traditional" cost modelling techniques [29]. Regression analysis and neural networks are modelling techniques applied to develop building cost estimation models [30]. McCaffer (1975) [31] and McCaffer et al. (1984) were the first to experiment this method for predicting construction costs at the early stage of a project [32]. Another application of this technique is provided by Trost and Oberlender (2003) [33]. Further review of the same application was presented by Skitmore and Patchell (1990) [34]. Emsley et al. (2002) applied a neural network approach to the forecast of total construction costs [35]. Elhag and Boussabaine $(2001,2002)$ applied it for the estimation of the tender price [36].

Recently, multiple linear regression methods were applied to wastewater treatment plants.

Papadopoulos et al. (2007) [37] compared the Ordinary Least Squares method with the Fuzzy Linear Regression applied to data on the construction, operation and maintenance costs of existing wastewater treatment plants in Greece. Rodríguez-Miranda et al. (2015) [38] developed a model function of the costs of existing treatment plants. The data collected and used in the model refer to the flow rate or capacity and to the water quality parameters (BOD, TSS, N, P).

Pinheiro et al. (2018) [39] used a simple linear regression analysis to obtain cost functions for five types of wastewater treatment plants (WWTP) based on their hydraulic and physical characteristics. Their results allow to assess the capital costs of new WWTP and the current value of existing assets at strategical and tactical planning levels without having data on the specific components of the facilities.

The present study provides a tool to estimate in advance the construction costs of a conventional urban wastewater treatment plants having medium-low capacity $(<50,000$ pe) and built according to a simplified processes diagram. It supports the technical and economic feasibility assessment of planned interventions carried out by both designers and public administration officials, which is a crucial phase in defining how to invest the available public financial resources and in verifying the sustainability of a project.

The research started with the analysis of 28 tenders awarded between 2001 and 2011 for the adjustment and new construction of wastewater treatment plants in the Sicily Region. The tender data was poor. Often, relevant information about the characteristics of the influent, the population served, the water supply, the geometry of the treatment units and the types of electromechanical equipment, was lacking.

Therefore, we decided to design nine urban wastewater treatment plants with low-medium capacity $(<50,000 \mathrm{pe})$ according to a simplified process scheme. In order to understand their expected construction costs, we adopted a methodology based on cost functions.

Construction costs were calculated according to two different procedures: a synthetic estimate of the costs for civil works, using parametric costs related to the pe whose data input were official price lists from the Sicily Region; and a multiple linear regression for the cost of the electromechanical equipment, whose data input were price lists of the companies producing these machines.

These functions enable the establishment of relationships between the construction costs and the population equivalent.

\section{Materials and Methods}

\subsection{Wastewater Treatment Plants}

Wastewater can have different origins. There are urban, industrial and agricultural origins of wastewater. Depending on the influent, the type and quantity of pollutants changes. Consequently, the treatment processes changes.

On the basis of pe number, natural systems are adopted for small communities $(<2000$ pe) while plant systems are adopted for large communities ( $>2000$ pe). Natural systems require large spaces but they have very low operating costs. Plant systems require smaller spaces, but they have high operating 
costs due to the electromechanical equipment that they use. Since 1914 the most common plant system has been activated sludge [40].

The variety of pollutants present in wastewater requires the adoption of specific processes. In fact, there are no processes or treatments that can be used for every type of discharge. Tables 1 and 2 [41,42] list the most common processes in use, respectively, for the removal of specific pollutants and for the treatment of sludge.

Table 1. Principle processes to remove specific pollutants.

\begin{tabular}{|c|c|}
\hline Pollutants & Processes \\
\hline Coarse materials & Grid removal \\
\hline Oils and fats & Grit and oil removal \\
\hline Suspended solids & Sedimentation \\
\hline Volatile compounds & Stripping \\
\hline $\begin{array}{l}\text { Biodegradable organic compounds } \\
\text { (low concentration) }\end{array}$ & Aerobic biological treatment \\
\hline $\begin{array}{l}\text { Biodegradable organic compounds } \\
\text { (high concentration) }\end{array}$ & Anaerobic biological treatment \\
\hline No-biodegradable organic compounds & $\begin{array}{l}\text { Adsorption on activated carbon } \\
\text { Membrane water purification } \\
\text { Ozonation } \\
\text { Wet oxidation } \\
\text { Incineration }\end{array}$ \\
\hline Biodegradable inorganic compounds & $\begin{array}{l}\text { Precipitation } \\
\text { Ion exchange } \\
\text { Membrane processes }\end{array}$ \\
\hline Cyanides, chromium & Redox \\
\hline Nitrogen compounds & Biological nitrification and denitrification Stripping \\
\hline Phosphorus & $\begin{array}{l}\text { Chemical precipitation } \\
\text { Biological phosphate removal }\end{array}$ \\
\hline Bacteria, virus & $\begin{array}{l}\text { Chlorination } \\
\text { UV irradiation } \\
\text { Disinfection } \\
\text { Ozonation } \\
\text { Lagooning }\end{array}$ \\
\hline
\end{tabular}

Table 2. Principle processes for sludge treatments.

\begin{tabular}{cc}
\hline Objective & Processes \\
\hline Thickener & Gravity thickening \\
\hline Organic compounds stabilization & $\begin{array}{c}\text { Anaerobic and aerobic digester Chemical sludge } \\
\text { treatment } \\
\text { Incineration }\end{array}$ \\
\hline Sanitation & $\begin{array}{c}\text { Pasteurization } \\
\text { Compost transformation }\end{array}$ \\
\hline Dehydration improvement & $\begin{array}{c}\text { Chemical sludge treatment } \\
\text { Thermal conditioning }\end{array}$ \\
\hline Dehydration & Centrifugation \\
& $\begin{array}{c}\text { Filtration } \\
\text { Drying }\end{array}$ \\
\hline Final disposal & Landfill \\
& Agricultural usage \\
\hline
\end{tabular}


Wastewater treatment is carried out through a series of operations combined to form the treatment cycle.

The configuration of plant also depends on the sensitivity of the area. According to the European Directive (91/271/EEC), the water discharged into the receiving bodies shall have specific quality requirements depending on the sensitivity of the area in which water is discharged. In addition, if the water is meant for reuse (irrigation, civil or industrial), the configuration of the plants changes because further refinement treatments has to be planned.

Before discharging into a receiving body, the wastewater shall be subjected to mechanical, biological and chemical treatment. Conventional activated sludge wastewater plants are classified as made according to using a "classic process diagram" (Figure 1a) or a "simplified process diagram" (Figure 1b).

Figure 1a shows a classic process diagram which includes a primary sedimentation process and an anaerobic sludge digester. Figure $1 \mathrm{~b}$ shows a simplified process diagram in which the primary sedimentation and anaerobic sludge digester are absent and an aerobic sludge digester is included.

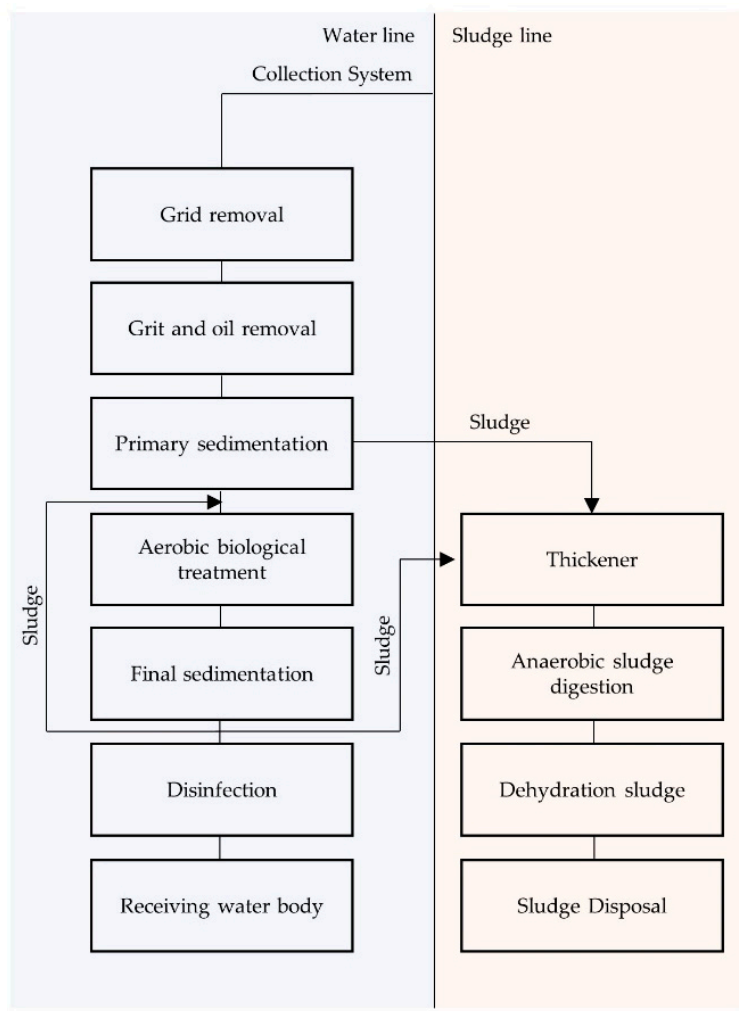

(a)

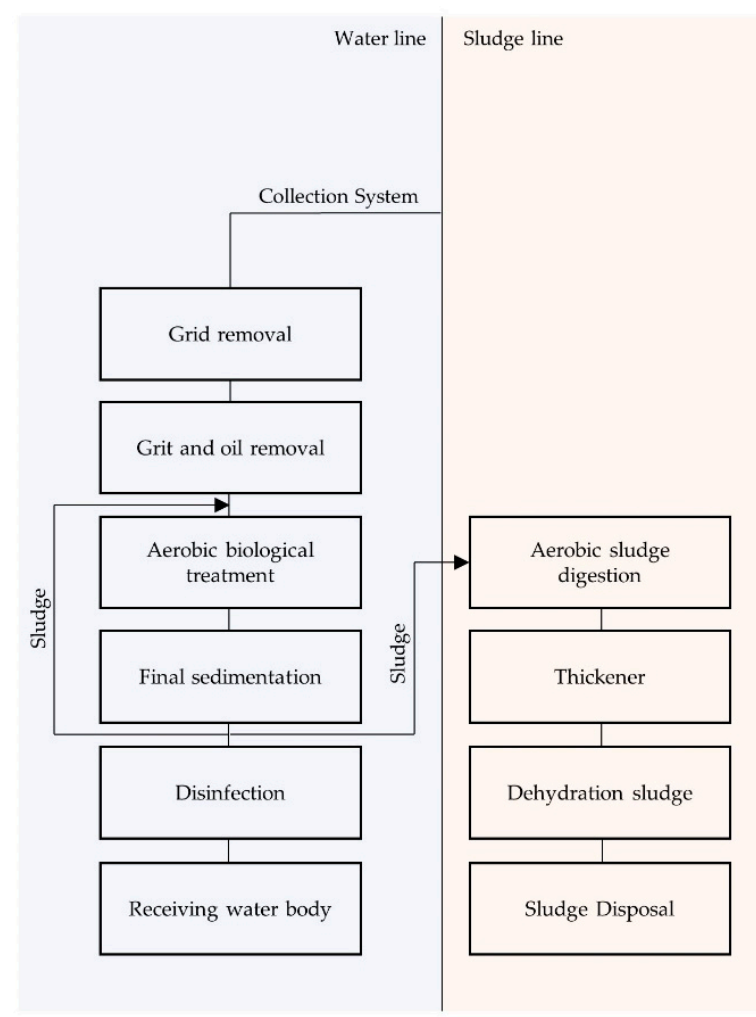

(b)

Figure 1. Process diagrams. (a) classic process diagram; (b) simplified process diagram [43].

This study focuses on the analysis of the construction costs of civil works and electromechanical equipment built according to a simplified processes diagram (Figure 1b).

All wastewater treatment processes take place in reinforced concrete tanks. Each of these tanks has a specific function and the polluting substances are separated there from the liquid mass also by means of specific electromechanical equipment. The equipment and its size is selected depending on the geometrical characteristics of each tank.

There are many types of electromechanical equipment that can be installed in each treatment unit. The most common types of electromechanical equipment in urban wastewater treatment plants are listed in Table 3.

Obviously, the list of equipment above cannot be exhaustive because there is a large variety of machines available. 
Table 3. Electromechanical equipment for each treatment units.

\begin{tabular}{ll}
\hline Grid removal & M_1 Sub-vertical bar screen \\
G_2 Arch-brush screen
\end{tabular}

\subsection{Cost Construction Evaluation}

Project choices have a significant impact on sustainability as management and construction costs depend on them. In the building sector, costs can be analyzed differently depending on the stakeholders involved in the production process:

- Total cost of production is crucial to the promoter of the building intervention;

- Construction cost is the main figure of interest to the construction company.

Construction cost $\left(C_{c}\right)$ includes the technical construction cost $\left(C_{t k}\right)$, construction and operating cost of the yard, the general costs of the company (we may assume $15 \%$ of the construction cost) $\left(S_{g}\right)$ and the entrepreneur's profit (we may assume $10 \%$ of the construction cost and general costs) $\left(U_{c}\right)[44]$.

$$
C_{c}=C_{t k}+S_{g}+U_{c}
$$

In particular, the technical construction cost $\left(C_{t k}\right)$ is made of: labor $\left(S_{a}\right)$, materials $(M)$ and freight/transport $\left(N_{t}\right)$ which are variable factors depending on the quantity of product to be manufactured and the time:

$$
C_{t k}=S_{a}+M+N_{t}
$$

Each project is defined by three levels of design:

- Technical-economic feasibility study;

- Final design;

- Executive design.

Three estimation procedures can be defined according to the design level (Table 4):

- Direct evaluation procedures (synthetical estimate);

- Indirect evaluation procedures (analytical estimate);

- Mixed evaluation procedures.

Table 4. Design levels and estimation procedures.

\begin{tabular}{ccc}
\hline Level Design & Estimation Procedures & Findings \\
\hline Technical-economic feasibility study & Synthetic procedure: & General preventive \\
Final and executive design & Parametric cost & Analytical procedure: \\
& Bill of quantities and prices analysis & Detail preventive \\
\hline
\end{tabular}


The synthetic estimation consists of forecasting the most likely cost value of a project by comparing it with known costs from similar projects carried out on the basis of appropriate parameterizations [45]. A specific parameter is chosen depending on the type of work. For example, square meters of surface area is used for residential construction, linear meters for plant pipelines, number of beds for hospitals, etc. The construction cost $\left(€ / \mathrm{m}^{2}\right.$ or $\left.€ / \mathrm{m}^{3}\right)$ is estimated by comparison with similar projects [44].

The analytical estimation consists of an estimate where there is no known scale of prices [46]. The analysis is carried out by comparing the identified working processes with the known costs of similar working processes that have already taken place. The process quantifies and gives an economic value to all production factors through unit prices [45].

In the final and executive designs, bills of quantities and prices analysis are used in order to carry out a detailed estimation. These tools allow the establishment of unit costs and reference parameters for each type of work, as well as the calculation of project quantities [44].

A high availability of historical costs is necessary for both procedures. For the synthetic estimation, price lists are used. For analytical estimation, informative price lists are used [47].

\section{Construction Cost of Wastewater Treatment Plants}

As with all industrial systems, also for wastewater treatment plants we can draw a distinction between capital and operating costs [48].

Capital costs are the costs necessary to carry out the work:

- Costs necessary for the construction of civil works;

- Costs necessary for the supply and installation of electromechanical equipment;

- Other expenditure such as VAT, design costs, contingency costs, etc.

Operating costs are the costs that the entity operating the plant has to bear annually to operate it efficiently:

- Staff;

- Electricity;

- Reactive agents;

- Ordinary and extraordinary maintenance.

Metcalf \& Eddy (2006) [42] lists the main aspects to consider when choosing a wastewater treatment plant. The most relevant are:

- Plant configuration;

- $\quad$ Equipment.

In an activated sludge plant, these are the factors that have the greatest impact on capital costs. As mentioned in Section 2.1, the configuration of a wastewater treatment plant depends on several factors (population equivalent, influent characteristics, effluent quality requirements, etc.).

Location is another key factor to set capital costs. Depending on the location of the treatment plant, environmental and landscape constraints must be checked. For example, the criteria for monitoring environmental impact in areas of value involve the total coverage of a plant. Therefore, the coverage of the plant increases construction costs significantly.

\subsection{Multiple Linear Regression}

The multiple linear regression method is often used to estimate construction cost [49]. It consists of developing a mathematical model that explains the relationship among several variables.

The aim is to find the value of a dependent variable as a function of a set of independent or regressor variables [50]. The method is used to measure the effect that independent variables have on the dependent variable [51]. 
The representative function of multiple linear regression with $p$ independent variables is a linear equation:

$$
y=\beta_{0}+\beta_{1} x_{1}+\beta_{2} x_{2}+\ldots+\beta_{p} x_{p}+\varepsilon
$$

where:

$\beta_{0}=$ intercept;

$\beta_{1}, \ldots, \beta_{p}=$ unknown numerical constants, called regression coefficients (they indicate a variation of $\mathrm{y}$ when $\mathrm{x}$ increases by one unit);

$x_{1}, \ldots, x_{p}=$ values assumed by known variables;

$\varepsilon=$ forecasted error, with expected value 0 and variance $\sigma^{2}$;

$y=$ unknown dependent variable.

The multiple regression model is based on the following assumptions:

- Linearity: The dependent variable $y$ can be expressed as a linear combination of the independent variables $x_{1}, \ldots, x_{k}$.

- Independence: Observations are selected independently and randomly from the population.

- Normality: Observations are normally distributed.

- Homogeneity of variances: Observations have the same variance [52].

The Ordinary Least Square (OLS) method is used in order to calculate the regression coefficients. It ensures that error is minimal, i.e., that the distance between the observed values $y_{i}$ and expected values $\hat{y}_{i}$ is minimal. Therefore, the equation can be expressed as:

$$
\begin{gathered}
\hat{y}=\beta_{0}+\beta_{1} x_{1}+\beta_{2} x_{2}+\ldots+\beta_{p} x_{p} \\
\varepsilon=y-\hat{y}
\end{gathered}
$$

from which:

$$
\sum_{i=1}^{n}\left(y_{i}-\hat{y}_{i}\right)^{2}=\sum_{i=1}^{n}\left(y_{i}-\hat{\beta}_{0}-\hat{\beta}_{1} x_{1}-\hat{\beta}_{2} x_{2}-\hat{\beta}_{p} x_{p}\right)^{2}=\text { min }
$$

The method calculates standard errors that measure the reliability of the estimates: the estimate is more reliable if the value of the standard error is smaller.

A fundamental parameter is the coefficient $R^{2}$ that allows to evaluate the adaptability of the estimated regression model. It can take a value between 0 and 1 . If the points are close to the line of the minimum squares, the coefficient $\mathrm{R}^{2}$ will be closer to 1 . As a result, adaptation will be better and vice versa.

The coefficient shall be adjusted to take account of possible added variables. In fact, the coefficient $\mathrm{R}^{2}$ tends to increase as the number of variables increases. Therefore, it is necessary to calculate a "corrected" or "adjusted" $\mathrm{R}^{2}$ that is used to measure the fraction of the explained deviation [51].

\section{Results}

\subsection{Estimation Method for Urban Wastewater Treatment Plants}

Our first goal in the research was to calculate the standard costs to estimate the procurement cost of construction of an urban wastewater treatment plant under various conditions, helping to set a reference for the estimated costs that the public authority bears to provide the service [53].

Following the example of the experiment carried out by the Supervisory Authority for Public Works [54], we applied the OLS method to correlate the construction cost of the wastewater treatment plant with the pe [55].

We first collected the data taken from the 28 tenders awarded between 2001 and 2011 for the revamping and new construction of wastewater treatment plants in the Sicily Region. 
The data was collected at the Department of Water and Waste at the Regional Department of Energy and Public Utilities of the Region of Sicily in Palermo. The documentation consists of general reports, bills of quantities, list and price analysis of the executive projects awarded.

The following activity was to create "data sheets" of the project which could be easily understood by the contracting authorities and by the administrations in charge of the control. The logic behind the data sheet is to divide the project into its different works. For each work more information was collected, including typological and quantitative characteristics. In the same sheet there is also the total amount of the cost work. The amount excludes the costs not strictly related to the dimensional parameters of the plant (for example, urbanization works and outdoor lighting).

The data collected showed that it is difficult to standardize the process of constructing water treatment the plants because:

- there are a vast number of design alternatives in terms of type, size and technology [21];

- the purification techniques offer numerous possibilities to achieve the same or similar results through different processes [6];

- local conditions, the location of the plant, the specific conditions of the land and urbanization works have a decisive influence on the construction cost even for plants having the same efficiency, population served, and flow rate treated;

- strong fluctuation in costs in the tenders analyzed was probably due both to the presence of few specialized companies that supply electromechanical equipment having a strong competitive position;

- price breakdown is lacking, which means that the differences among the plants are hard to detect.

To overcome these issues, we provide a more detailed analysis. The database showed that each civil work can be broken down in a number of processes that are not all necessarily carried out and are not all functions of the design parameters. In this regard, we identified the civil works that more often take place in each treatment unit to define a significant standard cost based on a few but fundamental pieces of information. The works that recur more often are excavations, concrete, formworks, steel, ironworks, landfill transport, hydraulic/electric works and electromechanical systems. Among them, the electromechanical works have the greatest impact on costs in the works to be carried out. Therefore, we decided to focus on these.

This first analysis indicated that the preliminary estimate of the construction cost of a plant could not be based solely on tenders' award.

\subsection{Synthetic Estimation for Construction Cost of Civil Works of Wastewater Treatment Plants}

The synthetic estimation procedure was used to carry out a preliminary estimation of the construction costs of the civil works. A fundamental step is to identify the most effective parameter to be applied to the type of project [56]. In this case, the parameter chosen was the Population Equivalent or pe, on which the flow rate of the water and the volume of the treatment units depend.

The proposed method for the parametric cost estimate was applied to an urban wastewater treatment plant according a simplified process diagram. Treatment units are shown in Figure $1 \mathrm{~b}$. The construction cost of each treatment unit was calculated based on a basic design of the wastewater treatment plants.

To this end we designed nine wastewater treatment plants with medium-low capacity $(<50,000 \mathrm{pe})$. They were thought to serve population equivalents of $5000 ; 10,000 ; 15,000 ; 20,000 ; 25,000 ; 30,000 ; 35,000$; 40,000 and 45,000 . Starting from a basic water supply of $200 \mathrm{~L} / \mathrm{pe} \cdot \mathrm{d}$, an increase depending on the demographic class and the relative urban and collective consumption was considered (Table 5) [41]. 
Table 5. Population Equivalent and water supply.

\begin{tabular}{ccc}
\hline pe & From 5000 to $\mathbf{1 0 , 0 0 0}$ & From 15,000 to 45,000 \\
\hline $\mathrm{L} /$ pe $\cdot \mathrm{d}$ & 280 & 300 \\
\hline
\end{tabular}

We designed the nine wastewater treatment plants taking into account the treatment of urban wastewater whose pro capite values of total suspended solids (TSS), organic load $\left(\mathrm{BOD}_{5}\right)$, nitrogen (N) and phosphorus $(\mathrm{P})$ are within the limits of rural or little industrialized centers as shown in Table 6 [57].

Table 6. Pro capite values.

\begin{tabular}{ccc}
\hline TSS & 90 & $\mathrm{~g} / \mathrm{pe} \cdot \mathrm{d}$ \\
\hline TDS & 100 & $\mathrm{~g} / \mathrm{pe} \cdot \mathrm{d}$ \\
\hline BOD $_{5}$ & 60 & $\mathrm{~g} / \mathrm{pe} \cdot \mathrm{d}$ \\
\hline $\mathbf{N}$ & 12 & $\mathrm{~g} / \mathrm{pe} \cdot \mathrm{d}$ \\
\hline $\mathbf{P}$ & 2 & $\mathrm{~g} / \mathrm{pe} \cdot \mathrm{d}$ \\
\hline
\end{tabular}

Considering the assumed pro capite values, the water supply and coefficient of inflow into the sewerage system of 0.8 , the pollutants concentrations are displayed in Table 7 [41].

Table 7. Concentration of pollutant.

\begin{tabular}{cccc}
\hline Water Supply & 280 & 300 & $\mathrm{~L} / \mathrm{pe} \cdot \mathrm{d}$ \\
\hline TSS & 402 & 375 & $\mathrm{mg} / \mathrm{L}$ \\
\hline TDS & 446 & 417 & $\mathrm{mg} / \mathrm{L}$ \\
\hline BOD5 & 268 & 250 & $\mathrm{mg} / \mathrm{L}$ \\
\hline $\mathbf{N}$ & 54 & 50 & $\mathrm{mg} / \mathrm{L}$ \\
\hline $\mathbf{P}$ & 8 & 8 & $\mathrm{mg} / \mathrm{L}$ \\
\hline
\end{tabular}

For the removal of suspended solids, biodegradable organic material and pathogens, seven underground reinforced concrete tanks were designed to be placed on a foundation slab. The building process for such tanks can be divided in the following phases:

- Excavations;

- Concrete;

- Formworks;

- Steel;

- Waterproofing;

- Landfill transport.

For each treatment unit and for each of the nine wastewater treatment plants, we calculated the quantity of civil works to be carried out in each phase. To obtain the construction costs we associated the quantities of these works to the unit prices of the Sicily Regional Price List 2019 [58]. This price list is for finished works and/or supplies with installation and takes into account labor, freight and transport costs, general expenses (assuming 15.00\%) and company profits (assuming 11.50\%).

The capital costs of the civil works for each treatment unit are shown in Table 8. (Table 9):

The capital costs should be adapted to the specific cases, by changing them [48] as following

- The construction costs of the hydraulic and electrical connections, as they are a function of the complexity of the plant and are higher for large plants, should compose between $15 \%$ and $20 \%$ of the treatment unit costs. 
- The costs for the arrangement of the plant area, which decrease when the dimension increases, should compose $35 \%$ of the treatment unit costs.

- The construction costs of the service structures, which increase when the dimension increases, should compose between $20 \%$ and $30 \%$ of the treatment unit costs.

Table 8. Parametric capital cost (€/pe) calculated for civil works of each treatment unit.

\begin{tabular}{cccccccccc}
\hline pe & $\mathbf{5 0 0 0}$ & $\mathbf{1 0 , 0 0 0}$ & $\mathbf{1 5 , 0 0 0}$ & $\mathbf{2 0 , 0 0 0}$ & $\mathbf{2 5 , 0 0 0}$ & $\mathbf{3 0 , 0 0 0}$ & $\mathbf{3 5 , 0 0 0}$ & $\mathbf{4 0 , 0 0 0}$ & $\mathbf{4 5 , 0 0 0}$ \\
\hline Grid chamber & 0.54 & 0.39 & 0.33 & 0.27 & 0.24 & 0.23 & 0.19 & 0.19 & 0.20 \\
Grit removal & 0.00 & 0.00 & 1.75 & 1.63 & 1.57 & 1.60 & 1.48 & 1.48 & 1.49 \\
Aeration tank & 10.27 & 8.65 & 7.86 & 7.48 & 7.19 & 6.98 & 6.84 & 6.68 & 6.60 \\
Sedimentation tank & 14.41 & 10.75 & 8.77 & 7.72 & 6.67 & 6.21 & 5.95 & 5.76 & 5.61 \\
Disinfection tank & 4.80 & 3.73 & 2.53 & 2.19 & 1.99 & 1.86 & 1.76 & 1.69 & 1.64 \\
Thickener tank & 1.12 & 0.82 & 0.75 & 0.74 & 0.75 & 0.62 & 0.66 & 0.70 & 0.62 \\
Sludge digestion tank & 20.71 & 17.18 & 15.58 & 14.70 & 14.10 & 13.67 & 13.33 & 13.06 & 12.84 \\
Parametric capital cost & $\mathbf{5 1 . 8 6}$ & $\mathbf{4 1 . 5 3}$ & $\mathbf{3 7 . 5 8}$ & $\mathbf{3 4 . 7 2}$ & $\mathbf{3 2 . 5 1}$ & $\mathbf{3 1 . 1 7}$ & $\mathbf{3 0 . 2 2}$ & $\mathbf{2 9 . 5 7}$ & $\mathbf{2 8 . 9 9}$ \\
\hline
\end{tabular}

Table 9. Total parametric capital cost $(€ /$ pe) for wastewater treatment plants with low-medium capacity $(<50,000$ pe).

\begin{tabular}{cccccccccc}
\hline pe & $\mathbf{5 0 0 0}$ & $\mathbf{1 0 , 0 0 0}$ & $\mathbf{1 5 , 0 0 0}$ & $\mathbf{2 0 , 0 0 0}$ & $\mathbf{2 5 , 0 0 0}$ & $\mathbf{3 0 , 0 0 0}$ & $\mathbf{3 5 , 0 0 0}$ & $\mathbf{4 0 , 0 0 0}$ & $\mathbf{4 5 , 0 0 0}$ \\
\hline $\begin{array}{c}\text { Total cost of civil work of } \\
\text { treatment units }\end{array}$ & 51.86 & 41.53 & 37.58 & 34.72 & 32.51 & 31.17 & 30.22 & 29.57 & 28.99 \\
$\begin{array}{c}\text { Costs of hydraulic and } \\
\text { electrical connections }\end{array}$ & 7.78 & 6.23 & 5.64 & 5.21 & 4.88 & 4.68 & 4.53 & 4.44 & 4.35 \\
$\begin{array}{c}\text { Costs of service structures } \\
\text { Costs for arrangement of }\end{array}$ & 14.00 & 13.00 & 15.12 & 13.98 & 13.09 & 12.55 & 12.16 & 11.90 & 11.67 \\
$\quad \begin{array}{c}\text { external area } \\
\text { Total parametric capital cost }\end{array}$ & $\mathbf{9 5 . 7 3}$ & $\mathbf{7 5 . 9 5}$ & $\mathbf{7 2 . 9 2}$ & $\mathbf{6 7 . 3 9}$ & $\mathbf{6 3 . 0 9}$ & $\mathbf{6 0 . 4 9}$ & $\mathbf{5 8 . 6 4}$ & $\mathbf{5 7 . 3 8}$ & $\mathbf{5 6 . 2 6}$ \\
\hline
\end{tabular}

The equation of the cost curve for wastewater treatment plants between 5000 pe and 45,000 pe is thus:

$$
€ / p e=705.33 \times p e^{-0.237}
$$

Figure 2 shows that the value of the coefficient $R^{2}$ is 0.9872 , showing that the curve represents very well the relationship between construction costs and the population equivalent.

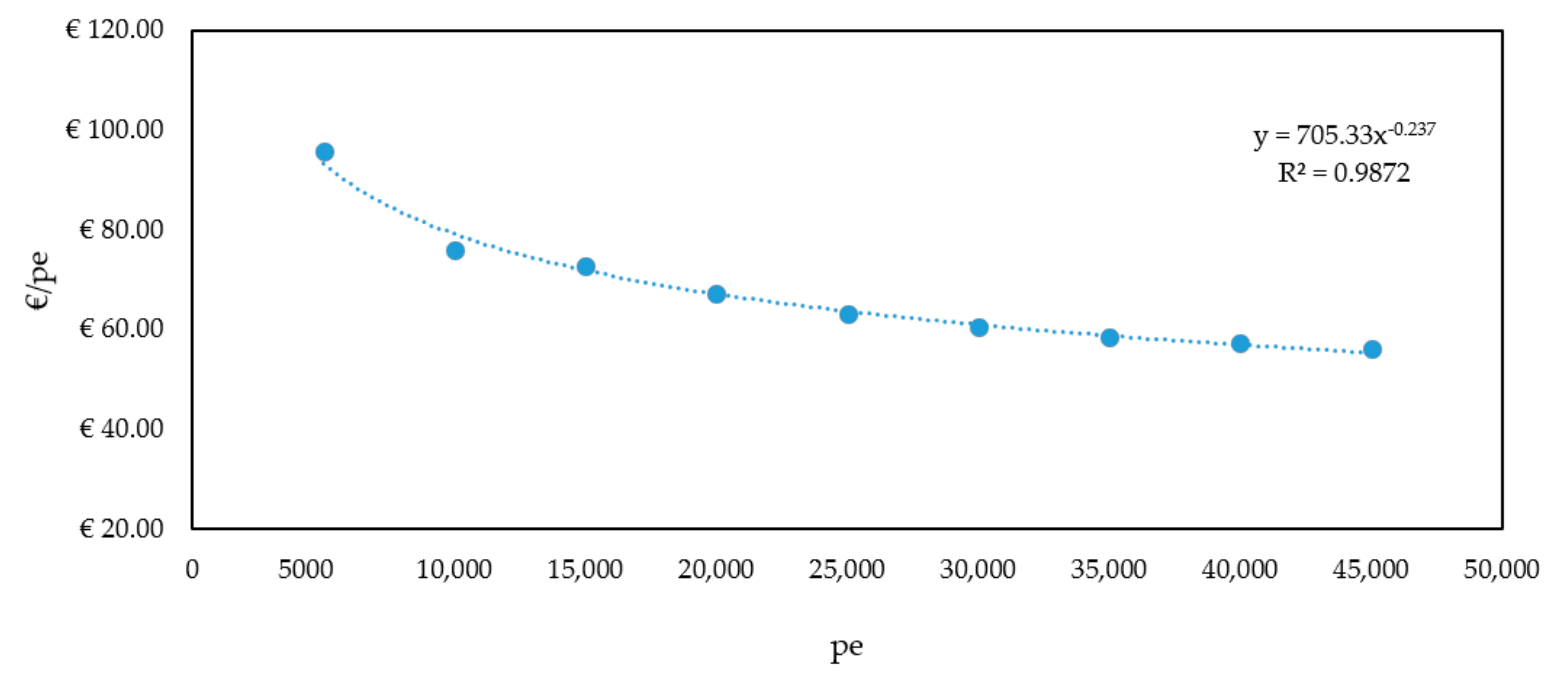

Figure 2. Cost curve for wastewater treatment plants with low-medium capacity $(<50,000 \mathrm{pe})$. 
As expected, the decreasing trend of the curve indicates that with the increase of the pe the unit cost decreases. The maximum unit cost was for 5000 pe and with a simplified process diagram was equal to $95.73 €$, while the minimum unit cost was for 45,000 pe and was equal to $56.26 €$.

It is noteworthy that the greatest economic benefit was obtained by increasing the size of a plant from 5000 pe to 10,000 pe as the unit cost fell by $20.00 € /$ pe, while from 10,000 pe to 45,000 pe the economic benefit was much lower, with the difference in unit cost ranging from just $5.00 €$ /pe down to $1.00 € /$ pe. When increasing the size of plants from 30,000 pe to 45,000 pe, there was practically no economic benefit.

Figure 2, therefore, shows that it is cheaper to build large wastewater treatment plants, especially up to 10,000 pe rather than many small ones, and this should be taken in consideration when sizing a plant. However, the economic benefits must be assessed also in relation to the sewage system and the operating costs.

\subsection{Cost Evaluation for Electromechanical Equipment}

Besides civil works, another key subgroup in wastewater treatment plant construction costs are related to the electromechanical equipment. Different types of equipment performing the same function can be installed in wastewater treatment plants. The type adopted depends on the design choices.

The machines analyzed refer to those more commonly used in the conventional wastewater treatment plants:

- Sub-vertical bar screen (M_1);

- Arch-brush screen (M_2);

- Grit and grease removal mechanical travelling bridge scraper (M_3);

- Tangential sand trap (M_4);

- Travelling bridge mechanical scraper clarifier for sedimentation tank (M_5);

- Peripheral drive circular clarifier for sedimentation tank (M_6);

- Sludge thickener with central drive for thickener tank (M_7);

- Belt-filter press for mechanical dehydration (M_8);

- Gas fluid compressor (M_9).

In the 28 tenders for wastewater treatment plants that we selected, we also observed a large fluctuation in the price for apparently similar electromechanical equipment. For this reason, we chose to apply a statistical method of multiple linear regression to predict the cost of such machinery [59].

In this case, as the Sicily Regional Price List 2019 did not supply any reference price, we had to directly collect the data from suppliers.

Eleven Italian companies specialized in the production of electromechanical equipment for treatment plants were contacted to deliver their price list. The price lists that were submitted refer only to supply of the machinery and exclude VAT, transport and assembly.

We observed that the price changed according to the geometric and performance characteristics of the individual device (width, length, height, diameter, power, etc.).

Our aim was to understand which of these characteristics has the greatest impact on the price of the machinery. Therefore, we applied the multiple linear regression method to find a cost function for each machine.

Analytically, the price was set as a dependent variable and the geometric and performance characteristics of the machine as independent variables (regressors).

The size of an electromechanical device was selected according to the size of the tank in which it is to be installed. The geometric and performance characteristics of each treatment unit are known by the preliminary design of the nine treatment plants.

Table 10 shows the geometric and performance characteristics of each device in relation to the pe. 
We skipped the M_2 and M_4 machines because they were not included in the plants that we designed and thus we could not know their geometric and performance characteristics, but only their prices which, as stated above, are not useful by themselves.

The cost function was applied to the nine electromechanical units included in our nine designs of wastewater treatment plants are shown in Table 11.

Table 10. Size of electromechanical equipment.

\begin{tabular}{|c|c|c|c|c|c|c|c|}
\hline \multirow[b]{2}{*}{ pe } & \multicolumn{2}{|r|}{ M_1 } & \multirow{2}{*}{$\begin{array}{c}\text { M_3 } \\
\text { Length } \\
\text { (L) (mm) }\end{array}$} & \multicolumn{2}{|c|}{ M_5 } & \multicolumn{2}{|c|}{ M_6 } \\
\hline & $\begin{array}{c}\text { Width } \\
\text { (L.C.) }(\mathrm{mm})\end{array}$ & $\begin{array}{l}\text { Discharged Height } \\
\text { (A.S.) }(\mathrm{mm})\end{array}$ & & $\begin{array}{l}\text { Diameter } \\
\text { (D) }(\mathrm{mm})\end{array}$ & $\begin{array}{l}\text { Power } \\
\text { (W) (kW) }\end{array}$ & $\begin{array}{l}\text { Diameter } \\
\text { (D) (mm) }\end{array}$ & $\begin{array}{l}\text { Power } \\
(\mathrm{W})(\mathrm{kW})\end{array}$ \\
\hline 5000 & 500 & 1100 & & 13,000 & 0.55 & 13,000 & 0.55 \\
\hline 10,000 & 600 & 1300 & & 18,000 & 0.55 & 18,000 & 0.55 \\
\hline 15,000 & 650 & 1450 & 8300 & 22,000 & 0.55 & 22,000 & 0.55 \\
\hline 20,000 & 550 & 1450 & 10,100 & 25,000 & 0.55 & 25,000 & 0.55 \\
\hline 25,000 & 1000 & 1400 & 11,600 & 27,000 & 0.55 & 27,000 & 0.55 \\
\hline 30,000 & 1300 & 1350 & 12,800 & 30,000 & 0.55 & 30,000 & 0.55 \\
\hline 35,000 & 1050 & 1550 & 13,400 & 32,000 & 0.55 & 32,000 & 0.55 \\
\hline 40,000 & 1400 & 1400 & 13,900 & 34,000 & 0.55 & 34,000 & 0.55 \\
\hline \multirow[t]{2}{*}{45,000} & 1800 & 1400 & 14,300 & 36,000 & 0.55 & 36,000 & 0.55 \\
\hline & \multicolumn{3}{|c|}{ M_7 } & \multicolumn{2}{|c|}{ M_8 } & \multicolumn{2}{|c|}{ M_9 } \\
\hline pe & $\begin{array}{l}\text { Diameter } \\
\text { (D) }(\mathrm{mm})\end{array}$ & $\begin{array}{l}\text { Height } \\
\text { (H) }(\mathrm{mm})\end{array}$ & $\begin{array}{l}\text { Power } \\
(W)(k W)\end{array}$ & $\begin{array}{l}\text { Length } \\
\text { (L) (mm) }\end{array}$ & $\begin{array}{l}\text { Power } \\
\text { (W) }(\mathrm{kW})\end{array}$ & $\begin{array}{l}\text { Flow rate } \\
(\mathrm{Q})\left(\mathrm{m}^{3} / \mathrm{h}\right)\end{array}$ & $\begin{array}{c}\text { Power } \\
\text { (W) }(\mathrm{kW})\end{array}$ \\
\hline 5000 & 4000 & 3800 & 0.55 & 500 & 0.55 & 187 & 5.5 \\
\hline 10,000 & 5000 & 4500 & 0.55 & 800 & 0.75 & 328 & 9.2 \\
\hline 15,000 & 6000 & 4500 & 0.55 & 1200 & 1.1 & 490 & 9 \\
\hline 20,000 & 7000 & 4400 & 0.55 & 1500 & 1.5 & 616 & 15 \\
\hline 25,000 & 8000 & 4200 & 0.55 & 2500 & 3 & 773 & 18.5 \\
\hline 30,000 & 8000 & 5000 & 0.55 & 2500 & 3 & 1007 & 22 \\
\hline 35,000 & 9000 & 4500 & 0.55 & 2500 & 3 & 1152 & 30 \\
\hline 40,000 & 10,000 & 4200 & 0.55 & 3000 & 3 & 1243 & 30 \\
\hline 45,000 & 10,000 & 4600 & 0.55 & 3000 & 3 & 1360 & 30 \\
\hline
\end{tabular}

Table 11. Cost functions for electromechanical devices. L.C. (Canal width), A.S. (Discharge height), D (Diameter), L (Length), H (Height), Q (Flow rate), W (Power).

\begin{tabular}{lll}
\hline Devices & Cost Functions & $\mathbf{R}^{\mathbf{2}}$ \\
\hline M_1 & $€=23,900-8.801$ (L.C.) $-0.961(\mathrm{~A} . S)+.0.003(\mathrm{~L} . \mathrm{C} .)^{2}+0.003(\mathrm{~L} . \mathrm{C} . \times$ A.S. $)-4254$ & 0.9607 \\
M_2 & $€=189$ (L.C.) & 0.974 \\
M_3 & $€=5327.496+1.5059(\mathrm{~L} . \mathrm{C})+.2.5204(\mathrm{D})-2222.038+5.4934(\mathrm{~L} . \mathrm{C})-.3.2146(\mathrm{D})$ & 0.9673 \\
M_4 & $€=7720+2.126(\mathrm{Q})-0.0000728(\mathrm{Q})^{2}+233.8-0.112(\mathrm{Q})$ & 0.991 \\
M_5 & $€=9082+2.662(\mathrm{~L})+26,920(\mathrm{~W})-8.102(\mathrm{~W})^{2}-9603$ & 0.9806 \\
M_6 & $€=9005+1.454(\mathrm{D})+9122(\mathrm{~W})-12570$ & 0.993 \\
M_7 & $€=35,480+0.5396(\mathrm{D})-8.216(\mathrm{H})-54,800(\mathrm{~W})+0.0005(\mathrm{D} \times \mathrm{H})+14.29(\mathrm{H} \times \mathrm{W})$ & 0.992 \\
M_8 & $€=2835+10.24(\mathrm{~L})-13,900(\mathrm{~W})+6.852(\mathrm{~L} \times \mathrm{W})+37,670$ & 0.9997 \\
M_9 & $€=5963-3.455(\mathrm{Q})+234.4(\mathrm{~W})+0.033(\mathrm{Q} \times \mathrm{W})$ & 0.952 \\
\hline
\end{tabular}

The price of each machine was determined by replacing the values listed in Table 10 in the equations in Table 11.

The geometric and performance characteristics (regressors) on which the price of each machine depends are summarized in Table 12. 
Table 12. Statistically significant independent variables for the determination of the price.

\begin{tabular}{|c|c|c|c|c|c|c|c|c|c|}
\hline Characteristics & M_1 & M_2 & M_3 & M_4 & M_5 & M_6 & M_7 & M_8 & M_9 \\
\hline Width (L.C.) & $x$ & $x$ & & & & & & & \\
\hline Length (L) & & & $x$ & & $x$ & & & $x$ & \\
\hline Height $(\mathrm{H})$ & & & & & & & $x$ & & \\
\hline Discharge height (A.S.) & $x$ & & & & & & & & \\
\hline Diameter (D) & & $x$ & & & & $x$ & $x$ & & \\
\hline Flow rate $(\mathrm{Q})$ & & & & $x$ & & & & & $x$ \\
\hline Power (W) & & & & & $x$ & $x$ & $x$ & $x$ & $x$ \\
\hline
\end{tabular}

Taking for example the M_7 machine model (sludge thickener with central drive), the estimated parameters together with their respective standards of error, $\mathrm{t}$-value and $p$-value significance level are displayed in Table 13.

Table 13. Machinery statistical data (M_7).

\begin{tabular}{cccccc}
\hline Coefficients & & Estimate & Std. Error & $\mathbf{t}$ value & $\operatorname{Pr}(>|\mathbf{t}|)$ \\
\hline (Intercept) & $\beta_{0}$ & $35,480.0$ & 5987.0 & 5.926 & 0.0000 \\
D & $\beta_{1}$ & 0.5396 & 0.7898 & 0.683 & 0.5037 \\
$\mathrm{H}$ & $\beta_{2}$ & -8.216 & 1.4780 & -5.559 & 0.0000 \\
$\mathrm{~W}$ & $\beta_{3}$ & $-54,800.0$ & $24,030.0$ & -2.280 & 0.0358 \\
$\mathrm{D}: \mathrm{H}$ & $\beta_{4}$ & 0.0005 & 0.000 & 2.945 & 0.0091 \\
$\mathrm{H}: \mathrm{W}$ & $\beta_{5}$ & 14.290 & 5.557 & 2.572 & 0.0198 \\
Multiple R $\mathrm{R}^{2}$ & 0.992 & & & & \\
Adjusted R & 0.9897 & & & & \\
\hline
\end{tabular}

In relating the diameter $(\mathrm{D})$, height $(\mathrm{H})$ and power $(\mathrm{W})$ of the machine to the price, the coefficient of determination $\mathrm{R}^{2}$ had a value equal to 0.992 which means that there was an excellent approximation to the observed data.

Referring to Equation (2) and the calculated statistical data, the cost function of the machinery M_7 was:

$$
\text { Price } €\left(M \_7\right)=35,480+0.5396 D-8216 H-54,800 W+0.0005(D x H)+14,290(H x W)
$$

If we attribute the values of the machine dimensions corresponding to 25,000 pe:

$$
\begin{aligned}
& D=8000 \mathrm{~mm} \\
& H=4200 \mathrm{~mm} \\
& W=0.55 \mathrm{~kW}
\end{aligned}
$$

it is possible to find le price of machine:

$$
€\left(M \_7\right)=26,337.10 €
$$

The parametric cost is:

$$
\frac{€}{p e}\left(M_{-} 7\right)=\frac{26,337.10}{25,000} \frac{€}{p e}=1.05 \frac{€}{p e}
$$

Table 14 shows the parametric costs of electromechanical equipment chosen for this study.

As for civil works, the unit costs of electromechanical equipment also had a decreasing trend as the population equivalent increased. 
The results show also that for these costs the economic benefit was the greatest when increasing the size of the plant and of its electromechanical equipment from 5000 pe to 10,000 pe; after which the increase resulted in smaller benefits.

Table 14. Parametric cost (€/pe) of electromechanical equipment.

\begin{tabular}{lccccccccc}
\hline & $\mathbf{5 0 0 0}$ & $\mathbf{1 0 , 0 0 0}$ & $\mathbf{1 5 , 0 0 0}$ & $\mathbf{2 0 , 0 0 0}$ & $\mathbf{2 5 , 0 0 0}$ & $\mathbf{3 0 , 0 0 0}$ & $\mathbf{3 5 , 0 0 0}$ & $\mathbf{4 0 , 0 0 0}$ & $\mathbf{4 5 , 0 0 0}$ \\
\hline M_1 & 3.61 & 1.83 & 1.23 & 0.92 & 0.78 & 0.70 & 0.58 & 0.55 & 0.55 \\
M_3 & 0.00 & 0.00 & 1.85 & 1.41 & 1.16 & 1.00 & 0.87 & 0.78 & 0.70 \\
M_5 & 5.03 & 3.05 & 2.39 & 1.92 & 1.64 & 1.46 & 1.40 & 1.36 & 1.33 \\
M_6 & 3.00 & 2.23 & 1.87 & 1.62 & 1.41 & 1.32 & 1.22 & 1.14 & 1.08 \\
M_7 & 2.87 & 1.86 & 1.44 & 1.21 & 1.05 & 0.98 & 0.87 & 0.80 & 0.76 \\
M_8 & 13.08 & 6.79 & 4.80 & 3.80 & 2.88 & 3.38 & 2.89 & 2.92 & 2.59 \\
M_9 & 1.33 & 0.71 & 0.43 & 0.38 & 0.32 & 0.28 & 0.29 & 0.25 & 0.21 \\
\hline
\end{tabular}

\section{Discussion}

The study refers to the costs of the civil works and of the electromechanical equipment of a typical civil urban wastewater treatment plant with low-medium capacity $(<50,000$ pe) built according to a simplified process diagram. The work has led to several remarks. Standard costs cannot be based on prices taken from public tenders because they are affected by multiple factors that cannot always be controlled and measured. In fact, one of the reasons for these costs fluctuations is that there is no reference price for processes commonly used in construction of a wastewater treatment plant.

Figure 2 shows a decreasing cost curve with increasing population equivalent (pe). The curve would seem to suggest that it is preferable to build centralized wastewater treatment plants to convey all the water to a single treatment plant, which would be sized for the corresponding pollutant load. But it should be noted that there are constraints to define the optimal size of a centralized system.

Several advantages, criticisms and limitations that take into account social, economic and environmental issues have to be considered [60].

Centralized wastewater collection and treatment systems are costly to build and operate, especially in areas with low population densities and dispersed households. Moreover, developing countries lack both the funding to construct centralized facilities and the technical expertise to manage and operate them. Alternatively, the decentralized approach for wastewater treatment which employs a combination of onsite and/or cluster systems is gaining more attention. Such an approach allows for flexibility in management, and simple as well as complex technologies are available. The decentralized system is not only a long-term solution for small communities but is more reliable and cost effective [61].

While centralized approach may have been suitable for maintaining low costs of construction, many agree that in face of a continually growing urban population and increasing water scarcity worldwide, a shift towards decentralization and source separation of domestic wastewater should be considered.

In fact, some of the issues driving the interest in decentralized systems, apart from declining local water sources, are financial efficiency, installation timeframe of infrastructures, water security, water loss derived from long distance transport, environmental degradation of aquatic habitats and local community empowerment [62].

\section{Conclusions}

The technical-economic feasibility study of a project is a crucial phase both for designers and for public administrations that have to deal with the limited resources available.

This article proposes a method to estimate in advance the construction costs of a conventional wastewater treatment plant with low-medium capacity $(<50,000 \mathrm{pe})$ according to a simplified process diagram (Figure 1b). Operating costs (staff, energy, reagents, etc.) are excluded from the study. 
The first step was to analyze the data collected from various tenders which showed that taking the data and relating it pe (Population Equivalent) does not lead to the definition of reliable standard overall construction costs. This is due to the multiple factors involved in defining the plant structure (such as influent characteristics, plants localization, and effluent quality requirements), whose impact is so strong that the overall construction cost of similar plants may greatly differ. Using population equivalent as a reference parameter is a valid approach to easily calculate the expected investment, but more in-depth study is needed in order to use it.

Therefore, we proceeded by breaking down the overall plant construction cost into its main parts and checked that the most significant ones are the costs for civil works and for electromechanical equipment. We focused on these two.

As far as the civil works are concerned, we calculated the quantity of such works to be carried out and their costs per each type of wastewater plant (we proceeded by designing nine of them ranging from 5000 pe to 45,000 pe). It appeared that the greatest benefit is obtained when increasing the size of a plant from 5000 pe to 10,000 pe (the decrease is almost $20.00 € /$ pe), while from 10,000 pe to 20,000 pe the economic benefit observed is smaller and from 20,000 pe to 45,000 pe is very little.

For the costs of the electromechanical equipment, we used multiple linear regression. The price was set as a dependent variable and the geometric and performance characteristics of the machines as independent variables (Table 11). The function thus obtained represents fairly well the real data as the adaptation coefficient $R^{2}$ ranges from 0.952 to 0.997 . The function shows that again the greatest benefit is when increasing the size of a plant from 5000 pe to 10,000 pe, especially due to the sharp decrease in the cost per pe of the belt-filter press for mechanical dehydration-a highly expensive component. Increasing the plant over 10,000 pe still brings some economic benefit especially up to 20,000 pe, beyond which the benefit tends to become clearly smaller.

The economic benefits of increasing the size of the plant up to 10,000 pe and over should be balanced by the costs of constructing collective sewerage networks and connecting structures between the cities.

The topic discussed is of current interest. To date, in fact, the community attributes to the protection of the environment an importance that must come to terms with the limited economic resources available.

Author Contributions: The study is the result of the work done jointly by the authors and coordinated by G.A.

Funding: Personal funding.

Conflicts of Interest: The authors declare no conflict of interest.

\section{References}

1. Council Directive 91/271/EEC of 21 May 1991 Concerning Urban Waste-Water Treatment. Available online: https://eur-lex.europa.eu/legal-content/EN/TXT/?uri=celex\%3A31991L0271 (accessed on 24 February 2019).

2. Report Controlli su Impianti di Depurazione 2018. Available online: https:/www.arpa.sicilia.it/wpcontent/uploads/2017/12/REPORT-CONTROLLI-SCARICHI-IDRICI-2018-dati-2017.pdf (accessed on 24 February 2019).

3. Verso una Economia Circolare. Available online: https://ec.europa.eu/commission/priorities/jobs-growthand-investment/towards-circular-economy_it (accessed on 4 March 2019).

4. 9th Technical Assessment on UWWTD Implementation. 2017. Available online: http://ec.europa. eu/environment/water/water-urbanwaste/implementation/pdf/9th\%20Technical\%20assessment $\% 20$ of $\%$ 20information\%20on\%20the\%20implementation\%20of\%20Council\%20Directive\%2091-271-EEC.pdf (accessed on 4 March 2019).

5. Sipala, S.; Mancini, G.; Vagliasindi, F. Development of a web-based tool for the calculation of costs of different wastewater treatment and reuse scenarios. Water Supply 2003, 3, 89-96. [CrossRef]

6. Hernandez-Sancho, F.; Molinos-Senante, M.; Sala-Garrido, R. Cost modelling for wastewater treatment processes. Desalination 2011, 268, 1-5. [CrossRef] 
7. Lim, S.R.; Park, D.; Park, J.M. Environmental and economic feasibility study of a total wastewater. J. Environ. Manag. 2008, 88, 564-575. [CrossRef] [PubMed]

8. Rodriguez-Garcia, G.; Molinos-Senante, M.; Hospido, A.; Hernadey-Sancho, F.; Moreira, M.; Feijoo, G. Environmental and economic profile of six typologies. Water Res. 2011, 45, 5997-6010. [CrossRef] [PubMed]

9. Molinos-Senante, M.; Hernández-Sancho, F.; Sala-Garrido, R. Economic feasibility study for wastewater treatment: A cost-benefit analysis. Sci. Total Environ. 2010, 408, 4396-4402. [CrossRef]

10. Godfrey, S.; Labhasetwar, P.; Wate, S. Greywater reuse in residential school in Madhya Pradesh, India-A case study of cost-benefit analysis. Resour. Conserv. Recycl. 2009, 53, 287-293. [CrossRef]

11. Seguí, L.; Alfranca, O.; García, J. Techno-economical evaluation of water reuse for wetland restoration: A case study in a natural park on Catalonia, Northeastern Spain. Desalination 2009, 246, 179-189. [CrossRef]

12. Chen, R.; Wang, X. Cost-benefit evaluation of a decentralized water system for wastewater reuse and environmental protection. Water Sci. Technol. 2009, 59, 1515-1522. [CrossRef] [PubMed]

13. Bergstrom, J.C.; Boyle, K.J.; Poe, G.L. The Economic Value of Water Quality; Edward Elgar Publishers: Cheltenham, UK, 2001.

14. Birol, E.; Karousakis, K.; Koundouri, P. Using economic valuation techniques to inform water resources management: A survey and critical appraisal of available techniques and an application. Sci. Total Environ. 2006, 365, 105-122. [CrossRef]

15. Del Saz-Salazar, S.; Hernández-Sancho, F.; Sala-Garrido, R. The social benefits of restoring water quality in the context of the Water Framework Directive: A comparison of willingness to pay and willingness to accept. Sci. Total Environ. 2009, 407, 4574-4583. [CrossRef]

16. De Martino, G.A. Costi e spese di esercizio degli impianti di depurazione. In Ingegneria Sanitaria; Istituto di Ingegneria Sanitaria del Politecnico di Milano: Milano, Italy, 1969; n.5; pp. 1-17.

17. Forte, C. I costi di urbanizzazione; Giuffrè, A.: Milano, Italy, 1971.

18. Iannelli, G. Il costo degli impianti di depurazione. Ing. Ambient. 1974, 3, 270-288.

19. Beccari, M. Costo degli impianti di depurazione delle acque di scarico urbane. In Quaderni IRSA; CNR: Roma, Italy, 1981.

20. D'Antonio, G.; Fabbricino, M.; Pirozzi, F. Model. Di Calc. Per La Valutazione Dell'elasticità Degli Impianti A Fanghi Attivi; Dipartimento di Ingegneria Idraulica Ambientale, Naples University: Napoli, Italy, 1998.

21. Irolli, V. La qualità dei Progetti di Opere Ambientali. Metodologia per la Rilevazione dei Costi Standard degli Impianti di Depurazione; Adriano Gallina Editore: Naples, Italy, 2003.

22. Onsite Wastewater Treatment System Manual. Available online: https:/www.epa.gov/sites/production/files/ 2015-06/documents/2004_07_07_septics_septic_2002_osdm_all.pdf (accessed on 10 March 2019).

23. CIRIA. Selection Package Wastewater Treatment Works; CIRIA Project Report; CIRIA: London, UK, 2001.

24. Upton, J.; Green, M.; Findlay, G. Sewage treatment for small communities: The seven Trent Approach. Water Environ. J. 1995, 9, 64-71. [CrossRef]

25. Geenens, D.; Thoeye, C. Cost efficiency and performance of individual and small-scale treatment plants. Water Sci. Technol. 2000, 41, 21-28. [CrossRef]

26. Pergetti, M.; Salsi, A. Analisi tecnico-economica sulle possibili soluzioni di gestione delle acque reflue urbane prodotte da piccolo agglomerate nella provincia di Reggio Emilia. Ing. Ambient. 2002, XXXI, 612-621.

27. Fortune, M.; Lees, M. The Relative Performance of New and Traditional Cost Models in Strategic Advice for Clients; RICS Research Paper Series; RICS Research: London, UK, 1996; p. 2.

28. Fortune, C.; Hinks, J. Strategic building project price forecasting models in use-Paradigm shift postponed. J. Financ. Manag. Prop. Constr. 1998, 3, 5-25.

29. Lawther, P.M.; Edward, P.J. Design Cost Modelling-A Way Forward. Aust. J. Construct. Econ. Build. 2001, 1, 32-42. [CrossRef]

30. Newton, S. An agenda for cost modelling research. Constr. Manag. Econ. 1991, 9, 97-112. [CrossRef]

31. McCaffer, R. Some examples of the use of regression analysis as an estimating tool. Quant. Surv. 1975, 81-86.

32. McCaffer, R.; McCaffer, M.; Thorpe, A. Predicting the tender price of buildings in the early design stage: Method and validation. J. Opl Res. Soc. 1984, 35, 415-424. [CrossRef]

33. Trost, S.; Oberkender, G. Predicting Accuracy of Early Cost Estimates Using Factor Analysis and Multivariate Regression. J. Constr. Eng. Manag. 2003, 129, 198-204. [CrossRef]

34. Skitmore, R.M.; Patchell, B.R.T. Developments in Contract Price Forecasting and Bidding Techniques; BPS Professional Books: Oxford, UK, 1990. 
35. Emsley, M.; Lowe, D.; Duff, A.; Harding, A.; Hickson, A. Development of neural networks to predict total construction costs. Constr. Manag. Econ. 2002, 20, 465-472. [CrossRef]

36. Elhag, T.; Boussabaince, A. Tender price estimation using artificial neural networks II: Modelling. J. Financ. Manag. Prop. Constr. 2002, 7, 49-64.

37. Papadopoulos, B.K.; Tsagarakis, K.P. Cost and Land Functions for Wastewater Treatment Projects: Typical Simple Linear Regression versus Fuzzy Linear Regression. J. Environ. Eng. 2007, 581, 133-136. [CrossRef]

38. Rodríguez-Miranda, J.P.; García-Ubaque, C.A.; Penagos-Londoño, J.C. Analysis of the investment costs in municipal wastewater treatment plants in Cundinamarca. DYNA 2015, 82, 230-238. [CrossRef]

39. Pinheiro, A.; Cabral, M.; Antunes, S.; Broco, N.; Covas, D. Estimating capital costs of wastewater treatment plants at the strategical level. Urban Water J. 2018, 15, 732-740. [CrossRef]

40. Masotti, L. Depurazione delle Acque. Tecniche ed Impianti per il Trattamento delle Acque di Rifiuto; Calderini: Milano, Italy, 2011.

41. Bonomo, L. Trattamenti Delle Acque Reflue; McGraw-Hill: Milano, Italy, 2008.

42. Metcalf \& Eddy Inc.; Wastewater Engineering. Treatment and Reuse; McGraw Hill: New York, NY, USA, 2003.

43. Campo, R.; Di Bella, G. Gli impianti di depurazione delle acque reflue: Tecnologie e prospettive. Ops Oss. Prezzi Sicil. 2017, 3, 11-31.

44. Roscelli, R. La valutazione di Fattibilità; De Agostini: Novara, Italy, 2014.

45. Utica, G.; Tomo, M. Metodi di Valutazione della Sostenibilità dei Progetti; Maggioli Editori: Milano, Italy, 2011.

46. Fabbri, L. Estimo civile e urbano; Edizioni Medicea: Firenze, Italy, 1985.

47. Realfonzo, A. Teorie e Metodi Dell'estimo Urbano; NIS: Roma, Italy, 1994; pp. 15-21.

48. Mancini, G.; Roccaro, P.; e Vagliasindi, F. Riuso delle acque reflue e costi di affinamento. In Processi e Tecnologie Innovative per la Depurazione delle Acque Reflue; Edizioni CSISA: Washington, DC, USA, 2006; pp. $247-297$.

49. Lowe, D.; Emsley, M. Predicting Construction Cost Using Multiple Regression Techniques. J. Constr. Eng. Manag. 2006, 132, 750-758. [CrossRef]

50. Seber, G.A.; Lee, A.J. Statistical Models. In Linear Regression Analysis; Wiley: Hoboken, NJ, USA, $2003 ;$ p. 557.

51. Montgomery, C.D.; Peck, E.A.; Vining, G. Introduction to Linear Regression Analysis, 4th ed.; John Wiley \& Son: Hoboken, NJ, USA, 2012.

52. Hair, J.; Black, W.; Babin, B.; Anderson, R.; Tatham, R. Multivariate Data Analysis, 6th ed.; Pearson Education: Upper Saddle River, NJ, USA, 2011.

53. Campo, O.; Rocca, F. La parametrizzazione delle quantità fisiche nella definizione dei costi parametrici. Il Decreto 50/2016 sulla progettazione delle opere pubbliche. Valori E Valutazioni 2017, 3, 3-9.

54. Metodo e Strumenti per la Determinazione dei Costi Standardizzati delle Opere Pubbliche in Rapporto al Tipo di Lavoro e alle Specifiche Aree Territoriali. Available online: https://www.anticorruzione.it/portal/rest/ jcr/repository/collaboration/Digital\%20Assets/Pdf/Cs110603.pdf (accessed on 10 March 2019).

55. Acampa, G.; Sollami, S.L. Costi standard: Una metodologia di determinazione applicata agli impianti di depurazione. Ops Oss. Prezzi Sicil. 2017, 3, 56-61.

56. Utica, G. La stima del costo di costruzione, 1st ed.; Maggioli Editori: Milano, Italy, 2011.

57. De Feo, G.; De Gisi, S.; Galasso, M. Acque Reflue. Progettazione e Gestione di Impianti per il Trattamento e lo Smaltimento; Dario Flaccovio Editore: Palermo, Italy, 2012.

58. Prezzario Regionale e Commissione Regionale LL. Available online: http://pti.regione.sicilia.it/portal/page/ portal/PIR_PORTALE/PIR_LaStrutturaRegionale/PIR_AssInfrastruttureMobilita/PIR_Infoedocumenti/ PIR_ALTRICONTENUTI/Prezzario\%202019\%20corretto.pdf (accessed on 15 March 2019).

59. Aiello, F. La regressione lineare multipla. Ops. Oss. Prezzi Sicil. 2017, 3, 72-75.

60. Libralato, G.; Volpi Ghirardini, A.; Avezzù, F. To centralise or to decentralise: An overview of the most recent trends in wastewater treatment management. J. Environ. Manag. 2012, 94, 61-68. [CrossRef]

61. Massoud, M.A.; Tarhin, A.; Nasr, J.A. Decentralized approaches to wastewater treatment and management: Applicability in developing countries. J. Environ. Manag. 2009, 90, 652-659. [CrossRef]

62. Opher, T.; Friedler, E. Comparative LCA of decentralized wastewater treatment alternatives for non-potable urban reuse. J. Environ. Manag. 2016, 182, 464-476. [CrossRef]

(C) 2019 by the authors. Licensee MDPI, Basel, Switzerland. This article is an open access article distributed under the terms and conditions of the Creative Commons Attribution (CC BY) license (http://creativecommons.org/licenses/by/4.0/). 